DOI: $\underline{10.7242 / 2658-705 X / 2019.4 .7}$

УДК 636.2:619:616.3+311(470.53)

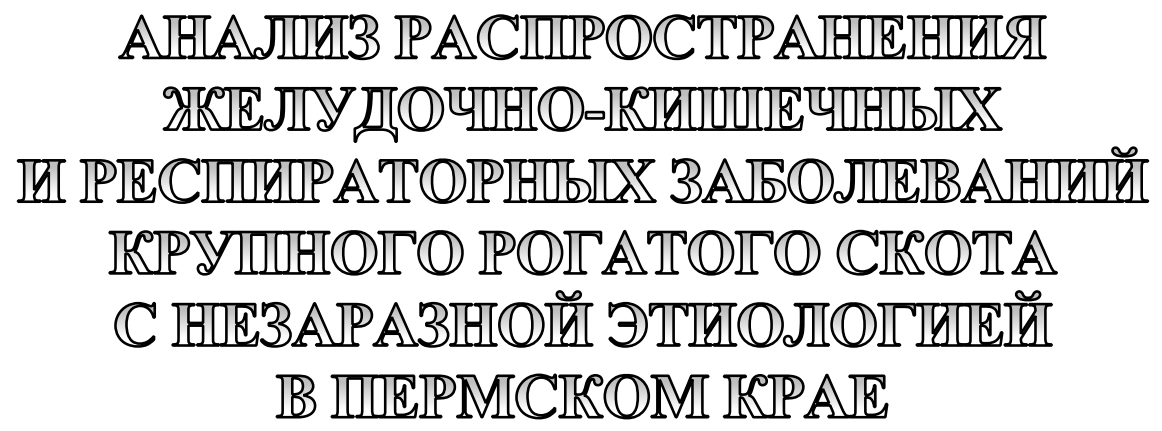

И.Н. Жданова, Пермский научно-исследовательский институт сельского хозяйства

Представлены результаты исследований по изучению распространённости желудочно-кишечных и респираторных заболеваний незаразной патологии у крупного рогатого скота в Пермском крае. Ведущее место из числа болезней крупного рогатого скота с незаразной этиологией занимают болезни органов пищеварения и дыхания. Основными предрасполагающими факторами возникновения этих заболеваний являются неполноценное кормление и болезни коров-матерей, нарушения технологии и гигиены вскармливания новорожденных телят и др. Ущерб от болезней органов пищеварения и дыхания складывается в основном за счёт гибели животных и вынужденного убоя. По данным ветеринарной отчётности Департамента ветеринарии при Министерстве сельского хозяйства в Пермском крае, за последние три года основной процент гибели животных приходится на взрослое поголовье крупного рогатого скота. По причине желудочно-кишечных заболеваний ежегодно гибло 43,7-45\% голов, от респираторных болезней 35,7-36,6\% от количества павших животных. Падеж телят по причине этих патологий за тот же период ежегодно составлял 38,5-40,0\% от числа павших, а вынужденный убой - 28,5-30,8\% от общего числа вынужденно убитых. Такой высокий уровень патологии требует со стороны ветеринарных специалистов и зоотехнических служб животноводческих предприятий принятия мер по устранению причин, вызвавших заболеваемость животных.

Ключевые слова: болезни органов пищеварения и дыхания крупного рогатого скота, гастроэнтериты, диареи, статистический анализ, молочное животноводство.

Наиболее острой проблемой современного животноводства являются незаразные болезни, широко распространенные среди всех видов и возрастов животных [4, с. 45-46].

Незаразные болезни - это заболевания сельскохозяйственных животных, возни- кающие в результате неправильного их кормления, содержания, ухода и хозяйственного использования. Незаразная патология крупного рогатого скота имеет широкое и повсеместное распространение [1, с. 12-13]. Данная проблема не менее актуальна и в Пермском крае, поэтому 
нами был проведён мониторинг распространения желудочно-кишечных и респираторных заболеваний болезней крупного рогатого скота незаразной этиологии.

Ежегодно в хозяйствах РФ, в том числе и в Пермском крае, желудочно-кишечными и респираторными заболеваниями болеют около $50 \%$ крупного рогатого скота, а падеж в первые дни жизни составляет от 14 до $60 \%$ [3, с. 83-84]. С внедрением в хозяйствах РФ, в том числе в Пермском крае, промышленной технологии ведения животноводства изменилась система содержания крупного рогатого скота. Новые технологические приемы (круглогодовое стойловое содержание, высокая концентрация животных на ограниченных площадях, отсутствие выгулов и инсоляции) при разнообразных климатических условиях республики повысили функциональную нагрузку на организм животных, что привело к увеличению болезней органов пищеварения и дыхания [5, с. 12-13].

Несмотря на это, многочисленные исследования показывают, что с ростом продуктивности коров увеличивается количество незаразных болезней животных, в первую очередь болезней органов пищеварения, преимущественно у молодняка. По мнению ряда авторов, болезни органов дыхания широко распространены во всех странах с развитым скотоводством, а к 2020 году прогнозируется увеличение их актуальности и они войдут в тройку лидеров причин гибели животных. Широкое распространение респираторной патологии также присутствует и в мясном скотоводстве: так, при анализе причин выбытия крупного рогатого скота мясных пород было выявлено, что у 23,3-41,8\% животных имеется патология органов дыхания. Некоторые авторы акцентируют внимание на развитии болезней органов дыхания, вызываемых, по принципу вторичных заболеваний, на фоне поражения желудочно-кишечного тракта. Особенно это касается животных крупных ферм и комплексов с высокоинтенсивной технологией производства молодняка, требующей решения целого ряда ветеринарно-сани- тарных, зоогигиенических, организационных, экономических и инженерно-технических вопросов [2, с. 35-36].

В странах с интенсивным молочным скотоводством большим препятствием на пути увеличения продуктивности животных служат болезни органов пищеварения и дыхания, от которых хозяйства несут большие потери. При заболеваниях органов пищеварения и дыхания, вызываемых необычными или экстремальными условиями кормления и содержания, учёные отмечают снижение резистентности, функциональные изменения в работе важнейших органов и систем и выраженные изменения физиологических отправлений и жизнедеятельности всего организма [8, с. 95-96].

На этом фоне отмечается увеличение количества мертворожденных, слабых, нежизнеспособных телят, что наносит животноводческим предприятиям всех категорий собственности огромный экономический ущерб, который складывается из снижения продуктивности, перерасхода кормов, преждевременной выбраковки, вынужденного убоя, падежа животных, затрат на лечение [7, с. 121-122]. Болезни органов пищеварения и дыхания отличаются своим разнообразным этиопатогенезом, помимо неинфекционной природы, отмечаются заболевания как инфекционного, так и инвазионного происхождения [3, с. 84-85]. Причины заболеваний органов пищеварения и дыхания у крупного рогатого скота:

- использование недоброкачественных кормов (прелого сена, заплесневелых концентратов и т.д.), недостаток воды;

- несвоевременная дача телятам молозива, выпойка холодного, кислого или загрязнённого молока и молозива, а также неправильная организация непосредственно процесса выпойки;

- резкие переводы телят на дальнейшие типы кормления молоком;

- нарушение технологических и санитарно-гигиенических условий содержания животных;

- чрезмерные стрессовые факторы (антисанитария, холод, сырость, плохая 
вентиляция, сквозняки, слабая освещенность, производственные шумы);

- нерациональное применение антибактериальных препаратов;

- иммунодефициты (неблагоприятная экологическая ситуация, при которой в кормах накапливаются токсические вещества: микотоксины, нитраты, нитриты, соли тяжелых металлов, хлорорганические соединения, радиоактивные вещества и др., отрицательно влияющие, в первую очередь на организм развивающегося плода и молодых животных);

- низкий уровень профилактической и лечебной работы. Нередки случаи, когда ветеринарные специалисты не принимают мер по выяснению причин болезни и установлению диагноза.

Отмечено, что после перенесения желудочно-кишечных (алиментарно-функциональных) и респираторных заболеваний в средней и тяжелой формах в раннем возрасте в дальнейшем у животных замедляется рост и развитие, снижается оплата кормов, от коров недополучают $15-18 \%$ возможной молочной продуктивности, возникают трудности в плодотворном осеменении [6, с. 45-46].

Цель исследований - проанализировать распространение заболеваний незаразной этиологии органов пищеварения и дыхания у крупного рогатого скота в Пермском крае.

\section{Результаты и их обсуждение}

За период 2016-2018 гг., согласно сведениям о незаразных болезнях животных (форма № 2-вет) по Пермскому краю, в животноводческих хозяйствах всех категорий в результате развития болезней незаразной этиологии пострадало 357831 голов крупного рогатого скота (таблица). При этом болезни органов пищеварения регистрировались в $24,5 \%$ случаев, у молодняка - в $18,8 \%$, органов дыхания - в $14,8 \%$, у молодняка - в $13,4 \%$ от общего количества поголовья. В том числе на молодняк крупного рогатого скота, от количества голов, страдающего болезнями органов пищеварения, пришлось 76,7\%; органов дыхания - 90,4\%.

В 2016 году болезни незаразной природы отмечались у 43,4\% животных от всего количества заболевших за изучаемый период, это на $0,7 \%$ выше, чем в 2017 году.

Несмотря на разницу в общем количестве заболевших животных в 2016 и 2017 годах, в процентном соотношении заболеваемость крупного рогатого скота, в том числе молодняка, патологиями со стороны желудочно-кишечного тракта была практически одинаковой и составила $24,5-25,1 \%$ и $18,2-18,3 \%$ соответственно. В 2018 году количество животных, подверженных заболеванию пищеварительной системы, уменьшилось на $0,9 \%$, а заболеваемость молодняка увеличилась на 1,5\% по сравнению с 2016 годом.

Таким образом, проведя статистический анализ за период с 2016 по 2018 год, необходимо отметить, что среди всей незаразной патологии болезни органов пищеварения отмечаются у 42-44\% заболевших от всего поголовья.

Анализ заболеваемости органов дыхания молодняка крупного рогатого скота,

Таблицча

\section{Мониторинг неинфекционной патологии органов пищеварения и дыхания крупного рогатого скота в Пермском крае}

\begin{tabular}{|l|c|c|c|}
\hline \multicolumn{1}{|c|}{ Наименование показателей } & \multicolumn{3}{|c|}{ Годы } \\
\cline { 2 - 4 } & $\mathbf{2 0 1 6}$ & $\mathbf{2 0 1 7}$ & $\mathbf{2 0 1 8}$ \\
\hline Количество заболевших, всего тыс. гол. & 114807 & 118795 & 124229 \\
\hline Из них болезнями органов пищеварения, всего & 28784 & 29040 & 29836 \\
\hline Из них молодняка, всего & 21037 & 21638 & 24572 \\
\hline Из них болезнями органов дыхания, всего & 17079 & 19244 & 16558 \\
\hline Из них молодняка, всего & 15965 & 17406 & 14440 \\
\hline
\end{tabular}


при нашем статистическом анализе за трёхлетний период, позволяет заключить, что заболеваемость телят респираторными заболеваниями будет подвержена колебаниям, но в целом останется на высоком уровне в случае, если не будут приняты особые меры профилактики.

В соответствии с таблицей заболеваемость в целом по незаразным болезням в Пермском крае повысилась к 2018 году до 92,4\%. Изменения в структуре заболеваемости крупного рогатого скота и молодняка являются незначительными заболеваемость респираторными заболеваниями снизилась с 14,9 до 13,3\%, у молодняка - на 2,3\%.

Наиболее общепризнанным и обоснованным мнением является то, что острые желудочно-кишечные болезни молодняка имеют различную природу. Острые расстройства функций желудка и кишечника у молодых животных могут быть самостоятельными заболеваниями незаразной природы, к ним относятся гастроэнтериты, диспепсии, гастриты, колиты, гастроэнтериты.

Нами был проведён мониторинг этиологии гастроэнтеритов молодняка крупного рогатого скота. Острые гастроэнтериты стоят на первом месте по отношению ко всем встречающимся болезням желудочно-кишечного тракта. Причина, чаще всего, по нашему мнению, кроется в несбалансированном рационе и нарушении кратности кормления. Рацион, несбалансированный витаминами и макро- и микроэлементами, приводит к развитию острого гастроэнтерита. На втором месте находится диспепсия. Мы предполагаем, что это также связано с кратностью кормления и выпойкой молозива или молока из ведра, большими глотками. Несвоевременное кормление телят приводит к образованию казеинового сгустка, который трудно поддаётся перевариванию и приводит к нарушению сычужного пищеварения. На третьем месте - гастроэнтериты, возникающие на фоне отравления. Связано это, скорее всего, с кормлением животных недоброкачественным, заплесневелым кормом. Скармливание кормов с высоким содержанием масляной кислоты (силос, сенаж, жом), нитритов, гербицидов, токсических грибов, приводит к отравлению с развитием острых гастроэнтеритов.

Из результатов мониторинга патологий органов дыхания у крупного рогатого скота наиболее распространённой оказалась острая катаральная бронхопневмония, а затем крупозная бронхопневмония, эмфизема лёгких, отёк лёгких и плеврит, встречались как единственное заболевание. Причиной бронхопневмонии являются простудные и другие заболевания, связанные с раздражением дыхательных путей. Особая восприимчивость отмечается у телят от коров голштинской породы, завезенных по импорту из Германии, которые проявляли повышенную чувствительность к респираторным заболеваниям, достигающую в отдельных случаях до 60\% от общего числа заболевших животных.

Основная масса телят заболевает в возрасте до одного месяца после перевода на групповое содержание. Значительную роль в возникновении респираторных болезней у молодняка играет технологический стресс. Во многих хозяйствах признаки у телят начинаются через 7-10 суток после перевода животных с индивидуального содержания на групповое. После попадания в группу начинает выстраиваться иерархия: животные конфликтуют между собой, конкурируют за корма и места отдыха. Чем больше группа, тем сильнее выражен стресс, который ведёт к снижению общей резистентности организма и ослаблению иммунитета.

Таким образом, исходя из полученных данных, можно сделать следующие выводы:

- за период 2016-2018 гг. в Пермском крае, в животноводческих хозяйствах всех категорий, у крупного рогатого скота в 42-44\% случаев регистрировалась патология со стороны пищеварительной системы неинфекционной патологии, в том числе от количества заболевших у молодняка - в 76,7\% случаев;

- на основе пояснительных записок к отчётам по форме 2-вет проведён анализ 
заболеваемости в Пермском крае желудочно-кишечными и респираторными заболеваниями взрослого поголовья и молодняка крупного рогатого скота, из которых превалируют острые гастроэнтериты, диспепсии и бронхопневмонии незаразной этиологии;

- анализ заболеваемости крупного рогатого скота болезнями органов дыхания в Пермском крае показал, что респираторные болезни телят широко распространены $(25-31 \%$ от числа всех заболевших незаразными болезнями). Данная патология протекает тяжело в возрасте перехода на групповое содержание животных;

- на возникновение и развитие респираторных болезней молодняка крупного рогатого скота существенное влияние оказывают факторы внешней среды, снижающие резистентность организма животных: условия содержания, микроклимат помещений, нарушение обменных процессов в результате неадекватного кормления, техногенные стрессы.

- наличие характерных клинических признаков заболевания, сопровождающихся выраженными диарейным и респираторным синдромами: тяжёлое течение с тенденцией к хронизации процесса, периодическое обострение воспаления в желудочно-кишечной и бронхолёгочной системах, является прямым показанием к поиску причин иммунной недостаточности у больных животных. Успешная реализация данной задачи возможна лишь при точном установлении дефекта в иммунной системе и выборе оптимальных средств для эффективной иммунокоррекции.
По результатам мониторинга исследуемых заболеваний определили актуальность проведения комплексных исследований по изучению этиологической структуры болезней органов пищеварения и дыхания у взрослого поголовья и молодняка крупного рогатого скота, поиску специфических препаратов, методов и схем их применения для повышения эффективности ветеринарных мероприятий. Поэтому для предупреждения заболеваний органов пищеварения и дыхания у крупного рогатого скота необходим детальный анализ эпизоотической обстановки в каждом конкретном хозяйстве, ферме наряду с анализом условий содержания, кормления животных, включая новорожденных телят и их матерей в период беременности, качества и безопасности для организма животных используемых кормов, соблюдения принятой в хозяйстве технологии выращивания телят. Важно определить полноту, своевременность и качество проводимых ветеринарно-санитарных мер, плановых диагностических исследований, вакцинаций животных, а также провести анализ результатов лабораторных исследований патологического материала от больных, павших животных и абортированных плодов за последние несколько месяцев.

Соблюдение ветеринарно-санитарных требований - является основой не только профилактики болезней молодняка и взрослого поголовья, но и важным условием повышения молочной продуктивности и качества молока.

\section{Библиографический список}

1. Арбузова A.A. Этиологические аспекты возникновения желудочно-кишечных заболеваний телят раннего постнатального периода // Учёные записки Казанской государственной академии ветеринарной медицины им. Н.Э. Баумана. - 2010. - № 200. - С. 12-17.

2. Герасимова Н.В., Курятова Е.В. Статистический анализ распространения болезней органов пищеварения крупного рогатого скота с незаразной этиологией в Амурской области// Дальневосточный аграрный вестник. - 2017. - № 1 (41). - С. 35-39.

3. Мотузко С.Н. Возрастные особенности амилолитической активности желудочно-кишечного тракта у коров // Учёные записки УО ВГАВМ. - 2015. - Т 51. - № 1. - Ч 2. - С. 84-87.

4. Методическое пособие по прогнозированию и ранней диагностике респираторных болезней у телят. / Черницкий A.E. [и др.]. - Воронеж; М.: Истоки, 2013. - 48 с.

5. Amrine D.E. Diagnosis and management of bovine respiratory disease. $-2013-130 \mathrm{p}$.

6. Effects of lactobacilli on parametrs of non- specific resistance of mice [Text] / Bloksma K., Ettekoven H., Hothuis F.M. [et. al.] // Med. Microbiol. Immunol. - 1981. - Vol. 170. - P. 45-53. 
7. Poulsen K.P., McGuirk S.M. Respiratory Disease of the Bovine Neonate // Veterinary Clinics of North America. - 2009. - Vol. 25. - P. 121-137.

8. Slivinska L. Demydjuk S., Shcherbatyy A., Mazurok P. Bronchopneumonia of calves: diagnosis and complex therapy // Науковий вісникЛьвівського національного університету ветеринарної медицини табіотехнологій ім. С.З. Гжицького. - 2016. - Т. 18. - № 2-3(71). - Р. 95-99.

\title{
ANALYSIS OF THE DISTRIBUTION OF GASTROINTESTINAL AND RESPIRATORY DISEASES OF CATTLE WITH NON-INFECTIOUS
}

\author{
I.N. Zhdanova
}

\section{Perm Scientific Research Institute of Agriculture}

The paper presents the results of studies on the prevalence of gastrointestinal and respiratory diseases of non-communicable pathology in cattle on the territory of Perm region. Diseases of the digestive and respiratory organs are the most common among cattle diseases with non-infectious etiology. The main predisposing factors for the occurrence of these diseases are inadequate feeding and diseases of mother cows, violations of technology and hygiene of feeding newborn calves, etc. The damage from digestive and respiratory diseases is caused mainly by the death of animals and forced slaughter. According to the veterinary reporting of the Department of Veterinary Medicine under the Ministry of Agriculture in Perm Region over the past three years, the main percentage of animal deaths occur in adult livestock of cattle. Due to gastrointestinal diseases, $43,7-45 \%$ of animals died annually, from respiratory diseases $35,7-36,6 \%$ of the number of dead animals. The death of calves due to these pathologies for the same period each year amounted to $38,5-40,0 \%$ of the number of fallen and forced slaughter $-28,5-30,8 \%$ of the total number of forced deaths. Such a high level of pathology requires veterinary specialists and zootechnical services of livestock enterprises to take measures to eliminate the causes of the incidence of animals.

Keywords: diseases of the digestive and respiratory organs of cattle, gastroenteritis, diarrhea, statistical analysis, dairy farming.

\section{Сведения об авторе}

Жданова Ирина Николаевна, кандидат ветеринарных наук, старший научный сотрудник лаборатории биологически активных кормов, Пермский научно-исследовательский институт сельского хозяйства - филиал Пермского федерального исследовательского центра УрО РАН (Пермский НИИСХ), 614532, Пермский край, Пермский район, с. Лобаново, ул. Культуры, 12; e-mail: saratov_perm@mail.ru 